\title{
3D cadastral standard definition and development using international standards for Turkey cadastral system
}

\author{
Mehmet Alkan ${ }^{1 *}$ (i), Hicret Gursoy Surmeneli ${ }^{1}$ (D) \\ ${ }^{1}$ Yildiz Technical University, Campus of Davutpaşa, Faculty of Civil Engineering, Department of Geomatic Engineering, Esenler, Istanbul, Turkey.
}

\begin{abstract}
In the last twenty years, cadastral definitions and terminology have been changed all over the world. For this reason, the two dimensional (2D) cadastral terminology has changed to the three dimensional (3D) cadastral context. The 2014 cadastral declarations do not utterly cover the 3D data model. In these contexts, some international standards have been developed for the cadastral process. LADM is to establish a common ontology for rights, responsibilities and restrictions (RRR) affecting the land administration and its geometric components. The other standards are the Infrastructure for Spatial Information in the European Community (INSPIRE) cadastral data themes that are compatible with the LADM data model. However, the INSPIRE cadastral parcels only deal with the geometric part of the cadastral data. Open Geospatial Consortium (OGC) conducts parallel works with ISO / TC 211 committee (ISO/TC 211 is a standard technical committee which is studied areas of digital geographic information and geomatics). OGC within its structure, ISO / TC211 and data standards are similar and compatible. ISO / TC 211 identify high-level and non-direct data models for geographic information producers and users. In this context, the Geo-Marking Language (GML) developed by OGC is a language that enables modelling, storage and sharing of the $3 D$ geometry. Also, it covers the attributes information of geographic objects according to the XML schema. The motivation of the study is to create a standard for a $3 D$ cadastral data model for Turkey by integrating standards with superior and different characteristics. The most important contributions of the study are the evaluation of the Turkish cadastral system within the scope of international standards (especially LADM) and demonstrating the comparability in the international platform. Another contribution is that the legal dimension of the cadastral system is modelled with international standards, and a model proposal is made for 3D cadastral data.
\end{abstract}

Keywords: 3D cadastre, LADM, International standards

Türkiye kadastro sistemi için uluslararası standartları kullanarak 3B kadastro standart tanımı ve gelişimi

Öz: Son yirmi yılda kadastro tanımları ve terminolojisi tüm dünyada değişmiştir. Bu nedenle, iki boyutlu (2D) kadastro terminolojisi üç boyutlu (3B) kadastro bağlamına dönüşmüştür. 2014 kadastral bildirimleri kadastro nesneleri için 3 B veri modelini kapsamamaktadır. Bu bağlamlarda, kadastro süreci için bazı uluslararası standartlar geliştirilmiştir. AİTM, arazi yönetimini ve geometrik bileşenlerini etkileyen haklar, sorumluluklar ve kisitlamalar (RRR) için ortak bir ontoloji oluşturmaktır. Diğer standartlar, AITTM veri modeliyle uyumlu olan Avrupa Topluluğu'ndaki Konumsal Bilgi Altyapısı (INSPIRE) kadastro veri temalarıdır. Ancak INSPIRE kadastro parselleri sadece kadastro verilerinin geometrik kısmı ile ilgilidir. Açık Coğrafi Konsorsiyum (OGC), ISO / TC 211 TC211 komitesiyle (ISO / TC 211, dijital coğrafi bilgi ve harita mühendisliği alanlarını inceleyen standart bir teknik komitedir) paralel çalışmalar yürütmektedir. OGC bünyesinde, ISO / TC211 ve veri standartları benzer ve uyumludur. ISO / TC 211, coğrafi bilgi üreticileri ve kullanıcılart için üst düzey ve doğrudan olmayan veri modellerini tanımlar. Bu bağlamda, OGC tarafindan gelişstirilen Coğrafi İşaretleme Dili (GML-Coğrafya Iş̧aretleme Dili) 3B geometrinin modellenmesini, depolanmasını ve paylaşılmasını sağlayan bir dildir. Ayrıca, (XML) şema yapısına göre coğrafi nesnelerin nitelik bilgilerini de kapsar. Çalışmanın temel amacı, standartları üstün ve farklı özelliklerle bütünleştirerek, Türkiye için bir $3 B$ kadastro veri modeli için bir standart oluşturmaktır. Çalışma dört ana aşamaya dayanmaktadır. İlk adım Türk kadastro sistemini açıklamaktır. Böylece sistemin avantajları ve dezavantajları tartışlmaktadır. Ikinci aşamada, uluslararası standartların uyumlaştırlması ve $3 B$ kadastroya katklları açıklanmıştır. Üçüncü aşamada, Türk kadastro sistemi, 3 B kadastro kapsamında mantıklı bir veri modelinin oluşturulmasıdır. Son bölümde modelin değerlendirilmesi, sonuçlar ve bulgular verilmiştir. Çalışmanın en önemli katkıları, Türk kadastro sisteminin uluslararası standartlar (özellikle AITTM) kapsamında değerlendirilmesi ve uluslararası platformda karşılaştırılabilir olduğunun gösterilmesidir. Bir diğer katkı, kadastro sisteminin yasal boyutunun uluslararası standartlara göre modellenmesi ve $3 B$ kadastro verileri için bir model önerisi yapılmasıdır.

Anahtar Sözcükler: 3B kadastro, LADM, Uluslararası standartlar 


\section{Introduction}

From the late 1990s onwards, the three dimensional (3D) cadastral work has been continuing in scientific and institutional terms all over the world. These studies are carried out within the framework of international standards and in the context of cadastre 2014 and 2034 declarations (Aien, 2013; Alkan, Gursoy Surmeneli \& Polat, 2018; Stoter, 2004). In Turkey, the management of rapid urbanisation, which is one of the signs and motors for the Turkey economic and land management development is a vital issue that depends on international standards development.

The International Organization for Standardization (ISO), the Infrastructure for Spatial Information in the European Comminty (INSPIRE) and the Land Administration Domain Model (LADM) standards for all over the world should press the cadastral systems. Although most legal cadastral systems provide the possibility to create property rights with 3D boundaries, the primary registration entity is mostly still in a 2D parcel. Moreover, the 2D cadastral system defines parcels according to the shape, spatial unit and parcel corner coordinates. On the other hand, 3D cadastral systems should be comprised of multi-level property situations that are not projected on the plane. Also, the plane cannot be used in the 3D data model and data schemas (Aien, 2013; Alkan et al., 2018; Stoter, Sørensen \& Bodum, 2004).

With respect to the 3D Cadastral systems within the scope of Cadastre 2034 vision, it was aimed to provide essential services expected from the cadastre such as knowing all rights, restrictions and responsibilities related to the real estates with these components, access to property and positional content and to direct the future cadastre with the developed policies, models and standards. These are more critical components for defining standards for the 3D cadastral systems.

There are many researches (Alkan et al., 2018; Benhamu \& Doytsher, 2003; Doner et al., 2010; Paulsson \& Paasch, 2011; Sorensen, 2011; Stoter \& Salzmann, 2003; Stoter \& van Oosterom, 2005) that have discussed the management of the 3D property in cadastral systems and acknowledged that a full 3D cadastre is the best solution. However, the most practical 3D cadastral systems are configured either with multi-layer parcels, such as in Israel (Benhamu \& Doytsher, 2003), or with 3D property objects registered on 2D cadastres, such as in Australia, Norway (Stoter \& van Oosterom, 2005), Malaysia (Hassan \& Rahman, 2011), and the Netherlands (Stoter, Ploeger \& van Oosterom, 2013).

In Turkey, cadastre comprises of two parts, which are land registry and spatial information with updated situation, which contains land-use components visualised by topographic symbols in 2D (Alkan \& Polat, 2017; Doner, 2010; Polat, Alkan \& Gursoy Surmeneli, 2017).

This paper is divided into six sections. Section one is the introduction, in which the motivation and aim of this research are described. The methodology of the study is described in section two. Section three describes the cadastral information system in Turkey that is currently in use and emphasizes the need for its improvement and explain international standards relations about cadastral system. Section four presents how to design and develop 3D cadastral data model by using international standards. Finally, section five and six are discussion and conclusion respectively.

\section{The Methodology of the Study}

This paper explores how the existing Turkish cadastral system can be addressed for the 3D object registration problem based on international standards. The 3D international standard represents 3D legal objects and connection with physical objects. In this regard, the 3D cadastral standard is equipped with the concepts of the Turkish cadastral system (Registration objects), project (Turkey's National Geographic Information System Project (Türkiye Ulusal Coğrafi Bilgi Sistemi, TUCBS)) and 
international standards such as LADM, INSPIRE and OGC.

To develop an experimental 3D cadastral data model for Turkish cadastral system, a methodology called design and development approach is shown in Figure 1. Throughout this design approach, Unified Modelling Language (UML) diagrams, along with textual and graphical descriptions, were used for the representation of all activities, processes, classes and associations.

In this study, the first two steps of the Turkish 3D cadastral system design approach was a review of existing standards, models and tools used in both disciplines with related to the international standards. The next step is the requirement analysis for 3D cadastral model based on international standards for Turkey. Then, a logical data model with international standards, namely LADM is designed. Finally, exploration of the discussion and conclusion parts are expressed in the paper.

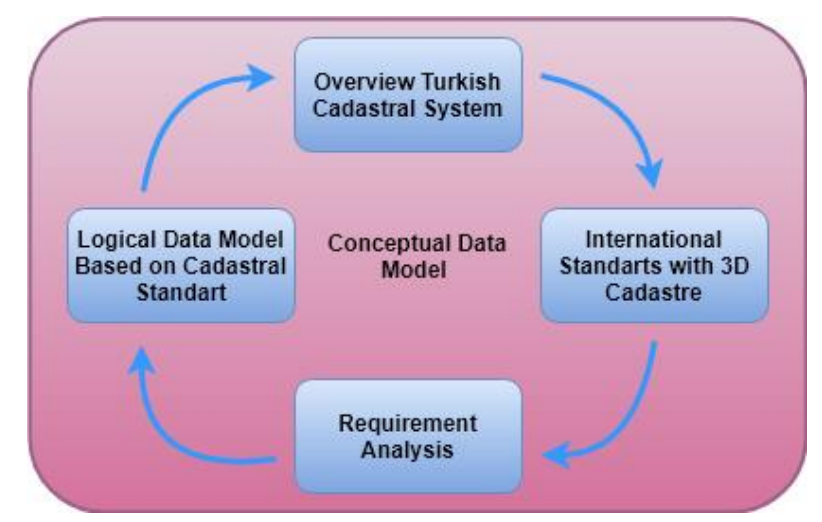

Figure 1: The methodology of the study

\section{Overview of Turkish Cadastral System}

Traditional cadastral systems have begun with dividing the land surface by 2D boundaries. For this reason, 2D parcels constitute the basic unit of the current cadastral maps. Nowadays in Turkey, cadastre system is based on 2D plots which are consists of two basic units, including land registration and cadastral mapping (Doner \& Biyik, 2007; Doner \& Biyik, 2013, Gursoy Surmeneli \& Alkan, 2018). In this context, the land registry records are officially formed by the title and the registry directorate and the maps by the cadastral branches. A 2D graphic representation of most rights, restrictions and responsibilities is possible. The rights, restrictions and responsibilities regarding the 3D are recorded as textual.

Although land parcels are represented as 2D, the use of parcels is volumetric. The use of 3D plots of volume parcels is provided by the real rights determined in the Civil Code. As a consequence, as stated by Doner (2010), legally, the property is already 3D. However, in cadastre, the spatial registration of the property is reduced into 2Ds. In time, the question rais es about whether the traditional cadastral registration based on the $2 \mathrm{D}$ parcel is sufficient to register all the conditions that emerged in the modern world (Rajabifard, 2014) or it is a necessity of a 3D approach for the cadastre (Doner \& B1y1k, 2007).

Several studies have been conducted in academic and institutional levels for 3D cadastre in Turkey. The common point of 3D cadastre studies emphasizes the modelling within a certain standard (Alkan, 2005; Aydin, 2008; Aydinoglu, 2010; Coruhlu, Demir, Yildiz \& Cete 2016; Doner, 2010; Gursoy Surmeneli \& Alkan, 2018; Karatas, 2007). Not only academic studies but also many institutional studies were conducted about standardization of the cadastral system. Some of them are Turkish Land Registry and Cadastre Information System (TAKBIS in Turkish), Land Registry and Cadastre Modernization Project (TKMP in Turkish), TUCBS. 
In this context, the cadastral systems of the countries described in the introduction section were examined. Also, the cadastral system in our country was evaluated. Evaluation of Turkish cadastral system within the scope of 3D Cadastre is shown in Table 1, according to the laws of the cadastral object to be registered in the cadastral system of Turkey. The criteria determined in Table 1 were obtained from the studies conducted in the cadastral book (van Oosterom, 2018).

Table 1: Evaluation of Turkish cadastral system within the scope of $3 D$ cadastre

\begin{tabular}{|c|c|c|c|c|}
\hline General Information & $\begin{array}{l}\text { Status 3D Objects' } \\
\text { Recording }\end{array}$ & $\begin{array}{l}\text { Right that can be } \\
\text { registered in 3D }\end{array}$ & $\begin{array}{l}\text { Legal Definition of } \\
\text { the 3D Objects }\end{array}$ & Existing 3D Object \\
\hline $\begin{array}{l}\text { - Civil law } \\
\text { - The right to property } \\
\text { is under state guarantee } \\
\text { - Title Law } \\
\text { - Cadastre Law } \\
\text { - Title registration } \\
\text { system } \\
\text { - Cadastral maps in } \\
\text { digital form } \\
\text { - Complete all cadastre } \\
\text { across the country } \\
\text { - Underground } \\
\text { structures are not } \\
\text { registered } \\
\text { - Cable, water, sewage } \\
\text { and telecommunication } \\
\text { lines are not recorded } \\
\text { - Condominium }\end{array}$ & $\begin{array}{l}\text { - } 2 D \text { registration } \\
\text { - Real estate, annex } \\
\text { and rights are } \\
\text { registered } \\
\text { - Condominium } \\
\text { registration } \\
\text { - Registration is } \\
\text { mandatory } \\
\text { - } 3 D \text { objects are } \\
\text { registered as } \\
\text { easement } \\
\text { - Easements are } \\
\text { represented in } 2 D \text { on } \\
\text { the cadastral map } \\
\text { - Architectural plans } \\
\text { include } 3 D \\
\text { information }\end{array}$ & $\begin{array}{l}\text { - Land, Parcel, } \\
\text { Buildings, } \\
\text { Independent } \\
\text { sections and Annex } \\
\text { are registered } \\
\text { - RRRs on } \\
\text { registered objects } \\
\text { are recorded } \\
\text { - Registered RRRs } \\
\text { are represented in } \\
2 D\end{array}$ & $\begin{array}{l}\text { - Registration } 3 D \\
\text { objects are recorded } \\
\text { with easements } \\
\text { - The type, scope and } \\
\text { application of } 3 D \\
\text { RRRs are defined in } \\
\text { the Civil and } \\
\text { Cadastral Law } \\
\text { - The law does not } \\
\text { have the necessary } \\
\text { explanations to } \\
\text { register } 3 D \text { objects }\end{array}$ & $\begin{array}{l}\text { - Buildings and annex } \\
\text { - Parcels } \\
\text { - Easement } \\
\text { - Condominium } \\
\text { - High voltage lines } \\
\text { - Oil and Natural Gas } \\
\text { Pipes } \\
\text { - Pylon locations } \\
\text { - Water channels }\end{array}$ \\
\hline Registered 3D Objects & $\begin{array}{c}\text { Presentation of 3D } \\
\text { Objects to Cadastral } \\
\text { Map }\end{array}$ & $\begin{array}{c}\text { Type of Cadastral } \\
\text { Parcel (2D / 3D) }\end{array}$ & $\begin{array}{c}\text { Projects related to } \\
\text { Cadastre }\end{array}$ & $\begin{array}{c}\text { Models related to 3D } \\
\text { / 4D Cadastre }\end{array}$ \\
\hline $\begin{array}{l}\text { - Buildings and annex } \\
\text { - Parcels } \\
\text { - Easement } \\
\text { - Condominium } \\
\text { - High voltage lines } \\
\text { - Oil and Natural Gas } \\
\text { Pipes } \\
\text { - Pylon locations } \\
\text { - Water channels }\end{array}$ & $2 D$ & $2 D$ & $\begin{array}{l}\text { - } 3 D \text { Cadastre } \\
\text { - TAKBIS } \\
\text { - TUCBS } \\
\text { - MEGSIS }\end{array}$ & - \\
\hline
\end{tabular}

\subsection{D International Cadastral Standards}

Nowadays the big question is whether the traditional cadastral registration based on 2D parcels is sufficient to register all the conditions that emerged in the modern world (Rajabifard, 2014) or it is a necessity of a 3D approach for the cadastre (Doner \& Biyik, 2007; Doner, 2010). Within this scope, studies have been carried out in International Federation of Surveyors (FIG), which is related with Cadastre 2014 vision and also now included in Cadastre 2034 vision as ongoing. Moreover, INSPIRE, LADM, ISO and OGC have standards for cadastral parcel and spatial object of the cadastral component. Up to now, the ideal cadastral system should have shown the entire legal status of the land including public rights, responsibilities and restrictions.

The first consideration of 3D cadastral issues at international level started in 2001. A study group, so-called 3D cadastres, established in 2002 within the body of FIG is working on the problems encountered in the transition to 3D cadastre and solutions. This commission has two main objectives. The first aim is to provide a universal concept and terminology in $3 \mathrm{D}$ cadastre. In this context, ISO 19152 (LADM) envisages the adoption of the Land Modelling Model (Doner et al., 2011). The second aim is to establish common structures in legal, institutional and technical terms to implement 3D cadastre (Doner et al., 2011). 


\subsubsection{The Land Administration Domain Model}

The 3D cadastre is a cadastre that provides information on the rights, responsibilities and restrictions on registration not only on the parcel but also the 3D possessive units (Stoter, 2004). In this context, the Land Administration Basic Model (LABM) constitutes a basic class to define the rights, responsibilities and restrictions concerning to the 3 dimension of the real estate. With this class structure, the management of the rights, responsibilities and restrictions that may occur on the spatial unit will be ensured.

The main starting point of the LADM is to establish a common ontology for rights, responsibilities and restrictions affecting the land administration and its geometric components. Thus, it will enable communication among related parties within a country or among different countries (Lemmen, van Oosterom \& Bennet, 2015; van Oosterom, Ploeger, Stoter, Thompson \& Lemmen, 2006). The LADM is developed in line with the Cadastre 2014 vision and complies with international ISO and OGC standards (Lemmen, van Oosterom, Uitermark, Zevenbergen \& Cooper, 2011; Tjia \& Coetzee, 2013). Besides, it has been conducted in the studies showing the compatibility of LADM with INSPIRE (Alkan \& Polat, 2017).

LADM has three main packages and one sub-package. These are LA_Party (Party package), LA_AdministrativePackage (Management package) and LA_SpatialUnitPackage (Spatial Unit package) and LA_SurveyingandRepresentation (Surveying and Representation sub-package) (Figure 2).

It also supports the time component of the LABM. The most important feature of the model is to be flexible and it can be expanded within specified standards. It is possible to associate with external classes such as Valuation, Address, and Landcover as required by the model feature.

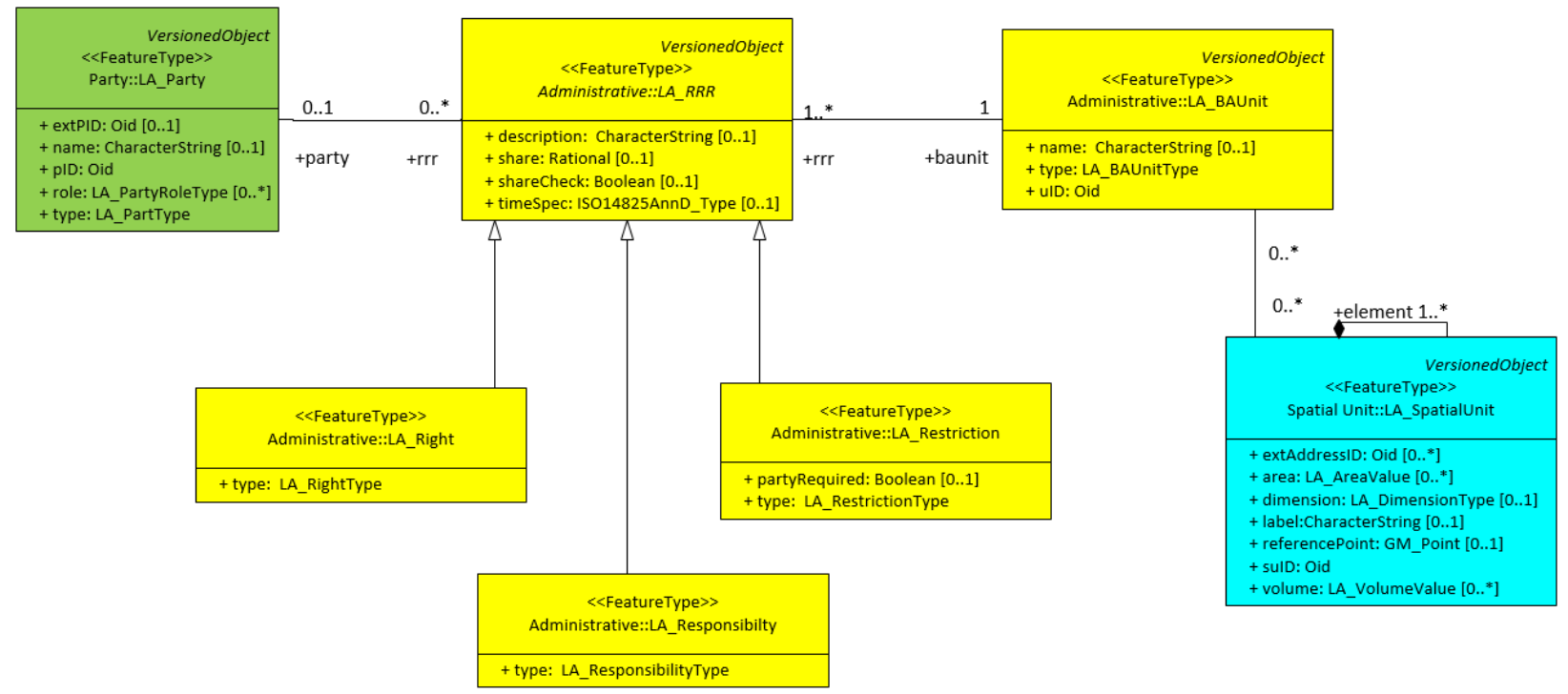

Figure 2: LADM core classes (Lemmen et al., 2015)

\subsubsection{Infrastructure for Spatial Information in Europe}

INSPIRE is an initiative introduced by the European Commission in 2001 together with the member states of the European Union (EU) (Akinci \& Comert, 2009; Aydinoglu, 2010; Mataraci, Yomralioglu \& Cete, 2009). The formation aims to identify, evaluate, monitor and implement EU policies, and to define the general framework. Within the framework of determination of the structure, the harmonisation of the spatial data between the member states of the EU and ensuring access to reliable and current spatial data is determined as the basic principle. In this context, the studies carried out in line with 
environmental policies, including agriculture, transportation and other sectors, at the local, regional and national levels, facilitated the access of the citizens and with corporation of environment to the spatial data.

The INSPIRE directives include 34 spatial data themes. Data themes such as land registry, administrative unit, address, building, land cover, land use are examples of these data themes. The data structure of the cadastral plots is simple, extensible and flexible. In this case, data providers contribute to the most appropriate and practical publication of their data (Aydinoglu \& Bovkir, 2017).

INSPIRE cadastral plot is compatible with the LADM data model. However, INSPIRE cadastral parcel only deals with the geometric part of cadastral data. It does not deal with property rights and legal parts on the parcel. However, in addition to the regular section, the LADM includes additional legal and proprietary information, such as rights, restrictions, responsibilities and parties to cadastral parcels.

\subsubsection{Open Geospatial Consortium Standards}

OGC is a non-profit industry association and consists of members working to ensure the interoperability of technologies within positional knowledge and to improve it (Ekin \& Cabuk, 2011). OGC conducts parallel works with ISO / TC211 committee. OGC within its structure, ISO / TC211 and data standards are similar and compatible (Aydinoglu, 2010). The vision of OGC is to provide a network, an application or a platform that can be used by anyone carrying out activities with geographical information or location information. Its mission is to make the spatial interface and technical coding standards available to all users (Ekin \& Cabuk, 2011). In line with its vision and mission, OGC produces direct sector-oriented standards for sharing the geographic information and interoperability in different software and hardware platforms. ISO / TC 211 identifies high-level and non-direct data models for producers and users of the geographic information. In this context, the GML developed by OGC is a language that enables the modelling, storage and sharing of the geometry. Also, attributes information of geographic objects are subjected according to the XML schema structure (Aydinoglu, 2007).

The TUCBS data model aims to establish a common data standard that different users and sectors need to share in Turkey. In this context, there should be a relationship between data groups and models in a different hierarchy. The institutional level is the lowest level of data. With this approach, TUCBS standards produced from the predictions of ISO, OGC and INSPIRE standards at international level; TAKBIS form the basis for data exchange in applications in different sectors (Aydinoglu \& Yomralioglu, 2010; URL-1; URL-2). Besides, TUCBS Conceptual Model comprises of the principles, reference model, scale-resolution and generalisation approaches, general detail model, detail catalogue, application scheme rules, geometry, topology, geographic object identification and temporal management, metadata, data quality and data sharing components. In this context, AD (Address), Building (Building), TK (Land Registry), IB (Administrative Unit), UL (Transportation), HI (Hydrography), AR (Land Cover) in the process of determining TUCBS standards based on conceptual model components are produced by using UML implementation schemes. In determining the conceptual data models of TUCBS data themes, the basic schemes of ISO / TC211 standards and other internationally accepted INSPIRE initiatives are adopted (Aydinoglu and Bovkir, 2017). Figure 3 shows data hierarchy between standards.

\section{Design and Develop 3D Cadastral Standards for Turkish Cadastral System}

Studies on the improvement of cadastral systems around the world and commission studies under FIG have demonstrated the need for the development of cadastral systems with a common standard. ISO / TC211, INSPIRE, OGC and ISO 19152 LADM standards have been developed for the organization of cadastral objects and geographical data. Many countries have implemented cadastral systems and modelled a common standard (Aien, 2013; Guo et al., 2013; Herdlevær, 2018; Steudler, 
2015; van Oosterom, 2018). Some academic studies in Turkey is emphasized that cadastral data should be modeled on common international standard (Alkan, 2005; Ayazli, 2006; Aydinoglu \& Inan, 2014; Cete \& Inan, 2013; Doner, 2010; Kumdakci, 2005). In this context, it is vital to model, analyze and question the cadastral data registered using international standards.

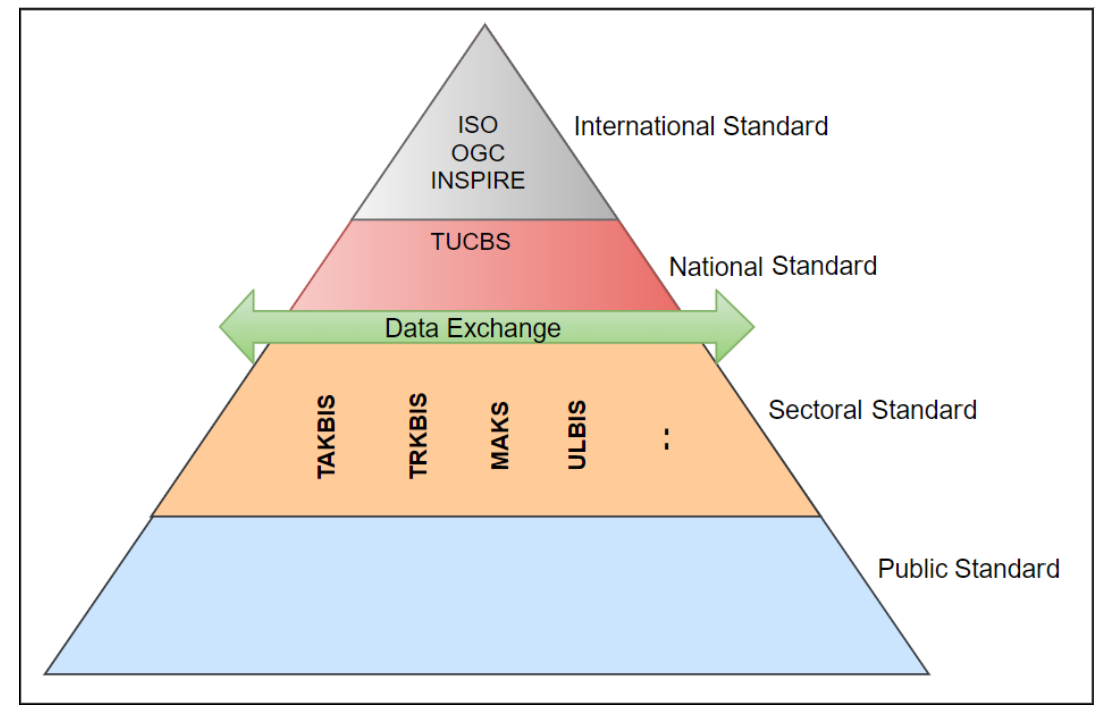

Figure 3: Data hierarchy between standards (URL-1)

When all these studies are evaluated, it is seen that there are studies aimed at improving the existing cadastral system. Besides, another common point of the studies is that the cadastral system is intended to be reshaped within the framework of ISO 19152 LADM, which is an international standard.

LADM standards are developed based on INSPIRE parcel data theme. Besides, according to the ISO 19109 Code of Practice Scheme accepted by OGC, implementation schemes for TUCBS data themes will be produced. The model designed in this study is associated with TUCBS cadastral parcel themes. In this context, the motivation of this research is the creation of a new standard model for the Turkish Cadastre System using Cadastre 2014, 2034 visions and INSPIRE, with storage, regulation, provisional inquiry and 3D land rights analysis, constraints, responsibilities and spatial unit. To this end, it will contribute to the TUCBS project and conduct a new standardization study for the Turkish cadastral system (Figure 4).

\subsection{Methods for using Cadastral Standards}

In the scope of this study, the following methods will be used in modelling a new standard.

- Qualitative and Quantitative research methods

- $\quad$ The vision of 2014 and 2034 Cadastre

- INSPIRE data themes

- $\quad$ OGC standard

- $\quad$ TUCBS Cadastre and Land Registry data theme

- $\quad$ ISO 19152, LADM. 
While both non-written (law, legislation, etc.) and numerical (database, data type, geometry) data will be used, qualitative and quantitative research methods will be utilized in this article. The Cadastre 2014 and 2034 visions, also set by FIG and Australia, have been adopted as guidelines. Accordingly, the criteria in the visions of Cadastre 2014 and 2034 approved by FIG were evaluated within the scope of our study. Case analysis method has been investigated how to keep records of cadastral data's attributes in Turkey. Besides, if the cadastral system of the country is examined, the 3D cadastral objects and their representation in the cadastral system would examined, as well (Table 1).

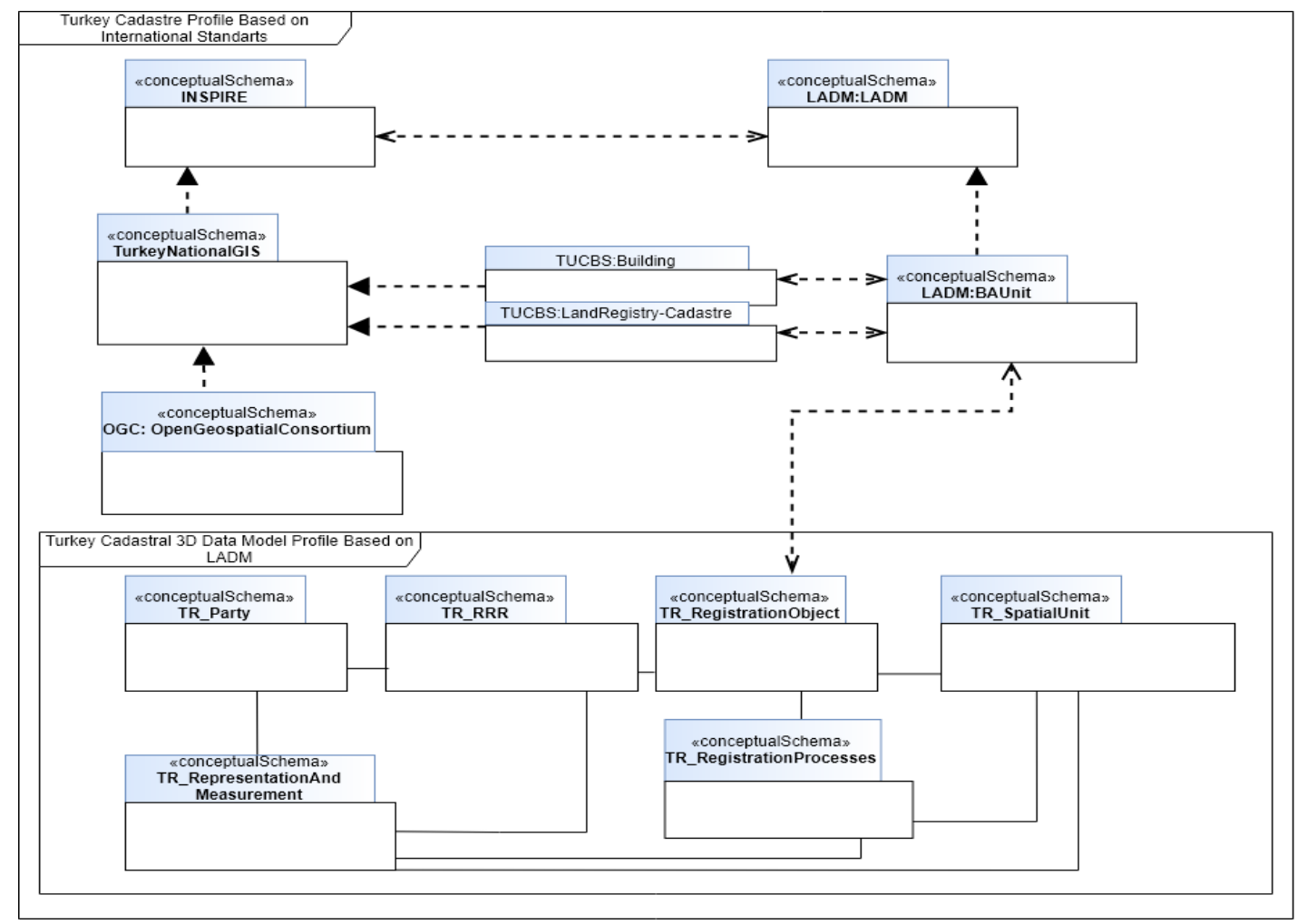

Figure 4: The general 3D cadastre profile based on international standards for Turkey

The quantitative component of the data-driven study explores how cadastral data are represented in Turkish cadastral system. The LADM data model was chosen within the scope of the study because it is an ISO standard, and it can serve better to the cadastral system in Turkey. Besides, INSPIRE, TUCBS and OGC standards are considered and taken as a basis in the model.

\subsection{Requirement Analysis}

Requirement analysis consists of steps as data modelling and database development processes. The necessity levels of requirement analysis can be listed as the collection and identification of critical objects and data elements. The main purpose of the requirement analysis is to define the information about the data and the relationships between each other (Simsion $\&$ Witt, 2005).

In order to manage the cadastral standards, which play an active role in the discipline of land management, it is essential to select the appropriate data value, determine the data types and characteristics and select an understandable modelling language. It is necessary to develop the most relevant international standard in line with the country profile.

The process steps performed within the scope of the requirement analysis of the proposed 3D cadastral data model with an international standard are listed as follows.

Determining the necessary data be used in the design: Qualitative and quantitative research methods were used to analyse the 
data. Also associated with the land registry and land management laws in Turkey (Civil Law, Land Law, Cadastre Law, Zoning Law, Condominium Ownership Act) was corrected by examining the shortcomings of the present system. Table 1 also shows evaluation of Turkish cadastral system.

Determination of the data types and properties to be used: The case analysis method was used for how the data were determined as a result of the current situation analysis. The title to be registered is examined, and necessary data types, characteristics and relationships between the data are determined. LADM that is the most suitable cadastral standard for Turkish cadastral system is selected. Besides, the data determined establish relationships between international standards.

Determination of logical data model: Basically, LADM, OGC, INSPIRE Cadastral Parcel data theme, Cadastre 2014 and 2034 visions were taken into consideration. In line with the basic structure of the Turkish cadastral system, the most appropriate data and data types for the $3 \mathrm{D}$ cadastral data model were created in Table 2 . In the consistent data, the model should consist of detail classes, attributes, values, names, relationships, multiplicities and constraints. Also, the data concepts to be used in the 3D cadastral data model are determined (Table 2 shows the general overview of logical data model).

Creation of conceptual data model: At this stage, the characteristics determined by the conceptual data model are expressed as UML within the logical data model. The identified relationships, concepts and definitions are defined in the model.

\subsection{Overview of the 3D Cadastral Standard}

In this section, the data to be used as a result of the requirement analysis and the data sets created are determined. The data to be used in the model as a result of the analysis are explained in Table 2. As the next process step, the data to be used in the model was matched with LADM and packages to be used in the model design were created (Figure 5). LADM model and 3D Cadastral data model are compared with similar and different aspects are shown (Figure 5). Mapping of the 3D cadastral data model packages and LADM packages is given. Then general overview of the data model packages is explained in this section. Table 2 describes the packages to be used in the model.

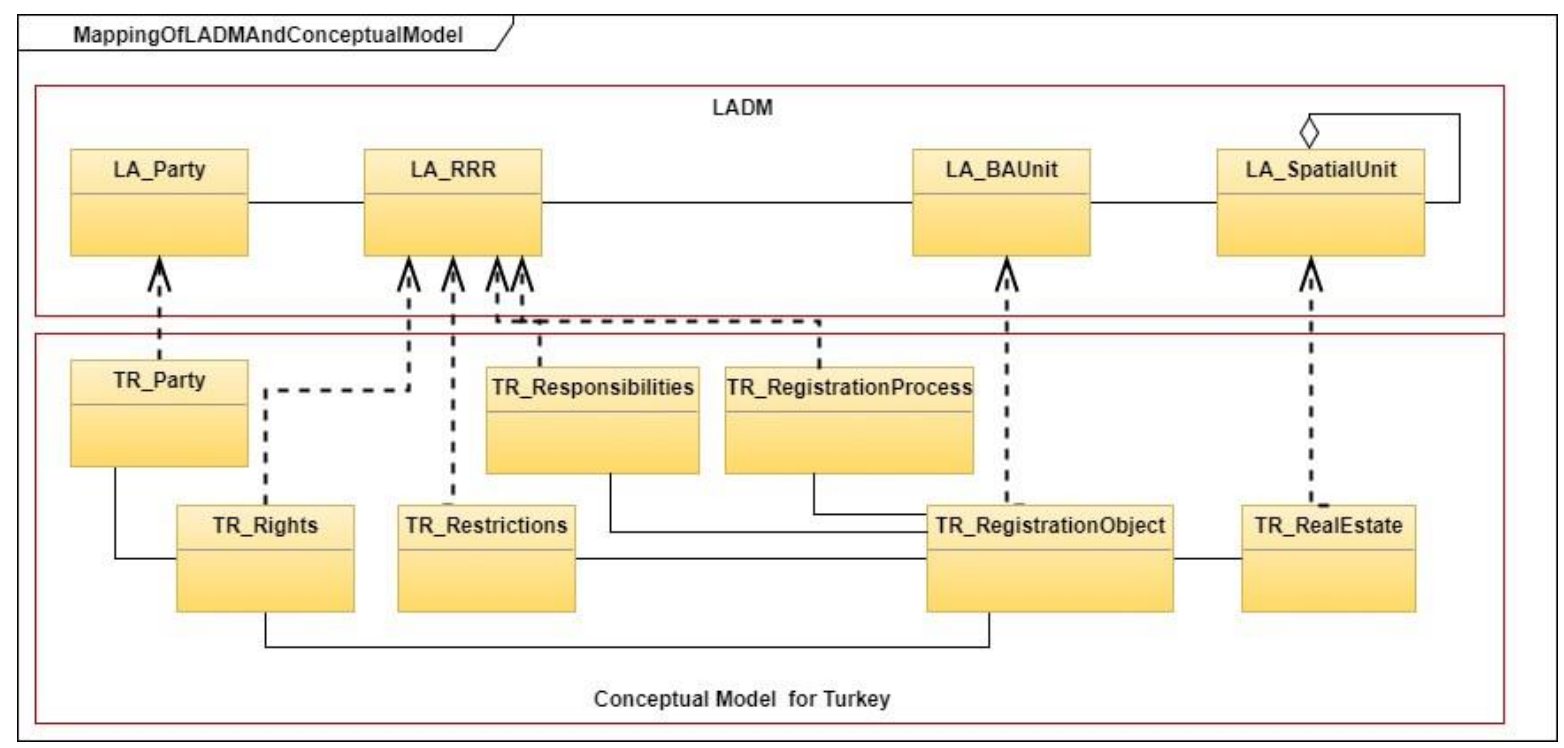

Figure 5: The conceptual model for Turkey

The 3D cadastral data model developed within the scope of the ISO 19152 and LADM standards is given in Figure 6. The model consists of 4 basic classes (TR_Party, TR_RRR, TR_RegistrationProcess and TR_RegistrationObject) and 24 subclasses such as TR_Right, TR_Representation, TR_GeometryProcess, TR_Point, etc. 
TR_Party is a class of ownership that corresponds to the LADM Party class in Turkish Cadastral System. It contains the ownership information about the owner of the immovable property.

Rights, Responsibility and Restrictions involve in TR_RRR package in which real or legal persons can make savings on a real estate. Also, at the same time, there may be some restrictions on real estate. Besides, the responsibility of the person against real estate is represented. The right class is divided into two sub-classes as property rights and limited rights in kind. The right to own property is the right of real or legal persons to make all kinds of savings, such as the use of property, use, purchase, sale, rent, lending on securities, real estate. A limited in-kind right permits the exercise of several rights on the property owned in contrast to the right to ownership of property. The limited real rights class is divided into two sub-classes as mortgage and easement. The restriction class is the part where the information is being restricted to the use of limited real rights is registered in the title registration and the part where the data is determined. These restrictions are subdivided into representations, rights and liability, annotations and mortgage rights in the land registry. Responsibility is the class in which a person's obligations to be fulfilled are represented. These obligations include the tax on the real estate, maintenance and repair according to the type of real estate, or regular payments and payment of the easement rights related to the real estate. There may be at least one or more types of responsibilities on an immovable.

TR_RegistrationProcess class has 3 sub-classes. These are TR_GeometryProcess, TR_LandUseConversion and TR_PropertyProcess. The types of geometry process such as subdivision, amalgamation and land subdivision are detailed in the Geometry process. The class of property process consists of transactions, such as sales and gratuity. Result in changes not only in the geometry of the property but also in its ownership. The land-use conversion process class only includes changes that occur in the type of real estate.

TR_RegistrationObject is the registration process for the person to become official with the title registration rights. The attributes in which the registered objects are registered in the positional unit package are represented. In this context, land, independent and permanent rights and independent sections are registered in the land registry. According to this definition, the registered object class includes land (zoning parcel, cadastral parcel), rights, restrictions and responsibilities on the immovable property, independent sections subjected to condominium ownership.

The SpatialUnit class is the parent class in which all cadastral objects are represented and associated with other classes. The positional unit comprises of parcel sub-classes, buildings and independent sections. The parcel class is the necessary objects of the cadastral system. The building class has a composition relation type with the parcel class. So every building must be on a parcel. The condominium is considered as a spatial unit. A building have none or more independent parts. According to the Property Law, the annex is outside of a condominium. Also, it is directly allocated to that section. The annex cannot be registered alone in the land register. Therefore, the type of $0 . *(0$-many) relationship is selected between the condominium and annex. The utility network, electricity, telephone, drinking water, sewerage, natural gas facilities are called as technical infrastructure facilities. In the existing cadastral system in Turkey, utility networks are not registered to the land registry. The existence of a utility network is associated with the parcel or building. In addition, there may not be any utility network equipment under or above each parcel and building. Therefore, the UtilityNetwork class has a type of $0 . .^{*}(0-$ many $)$ relationships with structure and parcel class. Since the land registry is not registered, the data related to the utility network facility cannot be kept directly in the system. Also, it can be provided with the external class, namely TR_ExternalUtilityNetwork.

Finally, the survey and representation sub-package involved in the model is the package in which the spatial objects and the geometric status are represented in the rights, restrictions and responsibility processes. The package represents geographic 
points, 2D and 3D borders, title and other resources. Attributes of the classes in the package have been created following the INSPIRE and LADM ISO19152 standards.

\section{Discussion}

With the development of modern technology, the 2D cadastre is no longer sufficient to meet property needs. In this context, international standards (LADM, cadastral 2014 and 2034 visions) have been defined to improve 3D cadastre. In line with these standards, many studies have been conducted in many countries. In Turkey, there are insufficient scientific studies on $3 \mathrm{D}$ cadastre. These academic studies can be categorized as direct and indirect cadastral studies. The studies carried out within the scope of 3D cadastre are generally aimed at analyzing the cadastral situation of the country, examining the use of easement rights and legal regulations arising from the third dimension and presenting sample database designs for local cadastral installation.

There is also a 3rd dimension to allow the registration of immovable in Turkey on the legal system. However, the representation of the 3rd dimension in cadastral maps is not possible in the current order. Several studies and projects are carried out in the institutional context to improve the Turkish cadastral system. In the institutional framework, there is insufficient information about the 3D cadastre project conducted by GDLRC (General Directorate of Land Registry and Cadastre). Furthermore, TUCBS studies conducted by the General Directorate of Geographical Information Systems of the Ministry of Environment and Urbanization do not yet have a data structure and model work in the context of 3D cadastre. Currently, efforts are underway to standardise and improve the existing cadastral system.

In this context, we determined the limits of our study as 3D cadastral legal object modelling. The standards used in the study and the types of relationships between cadastral objects are defined. Thus, a step was taken towards standardization for the Turkish cadastral system. One of the most important objectives of our study is to create a model in line with standardization. Secondly, the data to be used in the model by defining the standards were created according to the international literature. Table 2 shows the data and explanations used in the model. In addition, it was matched with LADM and the comparison of the Turkish cadastral system on the international platform was provided (Figure 5). Finally, LADM-based modelling of 3D cadastral legal data was performed. It has contributed to the literature regarding the 3D standardization of the Turkish cadastral system through all stages.

\section{Conclusion}

Over the last two decades, with the development of modern technology, the 2D cadastre has no longer been responded adequately to the property needs. In this context, 3D cadastre has come to the agenda instead of $2 \mathrm{D}$ cadastre, which is insufficient in terms of today's technology and property requirements. Within the scope of these results, many international studies are carried out (LADM, ISO standards, cadastre 2014 and 2034 visions). These studies continue in institutional and scientific dimensions. In our country, there is no institutional dimension. There are some scientific studies in Turkey. The studies carried out in this context were explained in the article. 
Table 2: 3D Cadastral data model identified for the using international standard

\begin{tabular}{|c|c|}
\hline Classes & Description \\
\hline TR_Party & It is a real and legal person who has the right to make any transaction on the real estate. \\
\hline$T R \_R R R$ & It is an upper class where Rights, Restriction and Responsibility classes are represented. \\
\hline TR_Right & $\begin{array}{l}\text { It is the state of being able to make all kinds of transactions on the real estate. The person has the } \\
\text { Property right and Limited Real Rights on the real estate. }\end{array}$ \\
\hline TR_Restriction & $\begin{array}{l}\text { It is the part where the information is restricting the use of limited real rights in the land registry. } \\
\text { These restrictions can be listed as representations, right and liabilities, annotations and } \\
\text { mortgage. }\end{array}$ \\
\hline TR_Responsibility & These are the obligations that a person must fulfil on the immovable property. \\
\hline TR_LimitedRealRight & The limited real rights are divided into two as Mortgage and Easement. \\
\hline TR_RealRight & $\begin{array}{l}\text { The right to property is the right of real or legal persons to make all kinds of savings, such as the } \\
\text { use of property, use, purchase, sale, rent, lending on securities, real estate. }\end{array}$ \\
\hline TR_Mortgage & $\begin{array}{l}\text { The mortgage is both a type of right and restriction. Some rights and restrictions may overlap, } \\
\text { such as the mortgage. The mortgage is registered in the land register as in the representations } \\
\text { process. }\end{array}$ \\
\hline TR_Easement & $\begin{array}{l}\text { The Easement right is a type of right that gives the right holder the right to use and benefit from } \\
\text { that real estate. }\end{array}$ \\
\hline TR_RightandLiability & $\begin{array}{l}\text { Rights and Liability class is the part where the rights such as easement, usufruct, right of access, } \\
\text { timeshare property rights are registered to the land registry. It is registered in its field as } \\
\text { representations. }\end{array}$ \\
\hline TR_Representation & $\begin{array}{l}\text { The Representation is the process of formalization of some issues regarding the actual and legal } \\
\text { status of the real estate. The representations are recorded in the land register. Also, the subject of } \\
\text { the transaction, the page number of the land register and the document number. }\end{array}$ \\
\hline TR_Annotations & $\begin{array}{l}\text { The Annotation process is the part of the restrictions for any immovable property. The annotation } \\
\text { process is registered in the area of the land register as in the representations process. }\end{array}$ \\
\hline TR_RegistrationProcess & $\begin{array}{l}\text { All changes in the land registry cadastre data are registered in the land registry and kept in the } \\
\text { archive system. These transactions are classified under the classes that change the Property } \\
\text { Process, Geometry Process and Land use conversion classes. }\end{array}$ \\
\hline TR_GeometryProcess & $\begin{array}{l}\text { The types of geometry process such as subdivision, amalgamation and land subdivision are } \\
\text { detailed in the GeometryProcess Class. }\end{array}$ \\
\hline TR_LandUseConversion & The land-use conversion process class only includes changes that occur in the type of real estate. \\
\hline TR_PropertyProcess & $\begin{array}{l}\text { This class consists of transactions, such as Sales and Gratuity. The result in changes not only in } \\
\text { the geometry of the property but also in its ownership. }\end{array}$ \\
\hline TR_RegistrationObject & $\begin{array}{l}\text { The real estate registered to the land registry is called registered objects. In this context, Land } \\
\text { (parcel), Independent and permanent rights (RRR, Registration Process) and Spatial Unit } \\
\text { (Building, Building Unit, Annex and Parcel) are registered in the land registry. }\end{array}$ \\
\hline TR_SpatialUnit & $\begin{array}{l}\text { The SpatialUnit class is the parent class in which all cadastral objects are represented and } \\
\text { associated with other classes. The positional unit consists of sub-classes of parcels, buildings and } \\
\text { independent sections. }\end{array}$ \\
\hline TR_Parcel & The parcel class is the primary class of the cadastral system. \\
\hline TR_Building & $\begin{array}{l}\text { The building class has a composition relation type with the parcel class. So every building must } \\
\text { be on a parcel. }\end{array}$ \\
\hline TR_BuildingUnit & The condominium is considered a spatial unit. A building can have no or more independent parts. \\
\hline TR_UtilityNetwork & $\begin{array}{l}\text { As Utility network, electricity, telephone, drinking water, sewerage, natural gas facilities are } \\
\text { called technical infrastructure facilities. In the existing cadastral system in our country, utility } \\
\text { networks are not registered to the land registry. The existence utility network is associated with } \\
\text { the parcel or building through which it passes over or under. }\end{array}$ \\
\hline TR_Annex & $\begin{array}{l}\text { According to the Property Law, the Annex is outside of a condominium. Besides, it is referred to } \\
\text { directly as allocated to that section. The annexe cannot be registered alone in the land register. }\end{array}$ \\
\hline TR_BoundaryFaceString & $\begin{array}{l}\text { The BoundaryFaceString class is the classes used to represent the boundaries of the spatial unit } \\
\text { in } 2 D \text {. }\end{array}$ \\
\hline TR_BoundaryFace & BoundaryFace class is the classes used to represent the boundaries of the spatial unit in $3 D$. \\
\hline TR_Point & $\begin{array}{l}\text { The point class is the base class of the SurveyandRepresentation Sub-package. It is associated } \\
\text { with the SpatialUnit class directly. }\end{array}$ \\
\hline TR_Source & $\begin{array}{l}\text { The Source class is the class in which all kinds of geometric or written resources are represented } \\
\text { related to Point, SpatialUnit, RegisterObject, RRR, RegistrationProcess and Party classes. }\end{array}$ \\
\hline
\end{tabular}




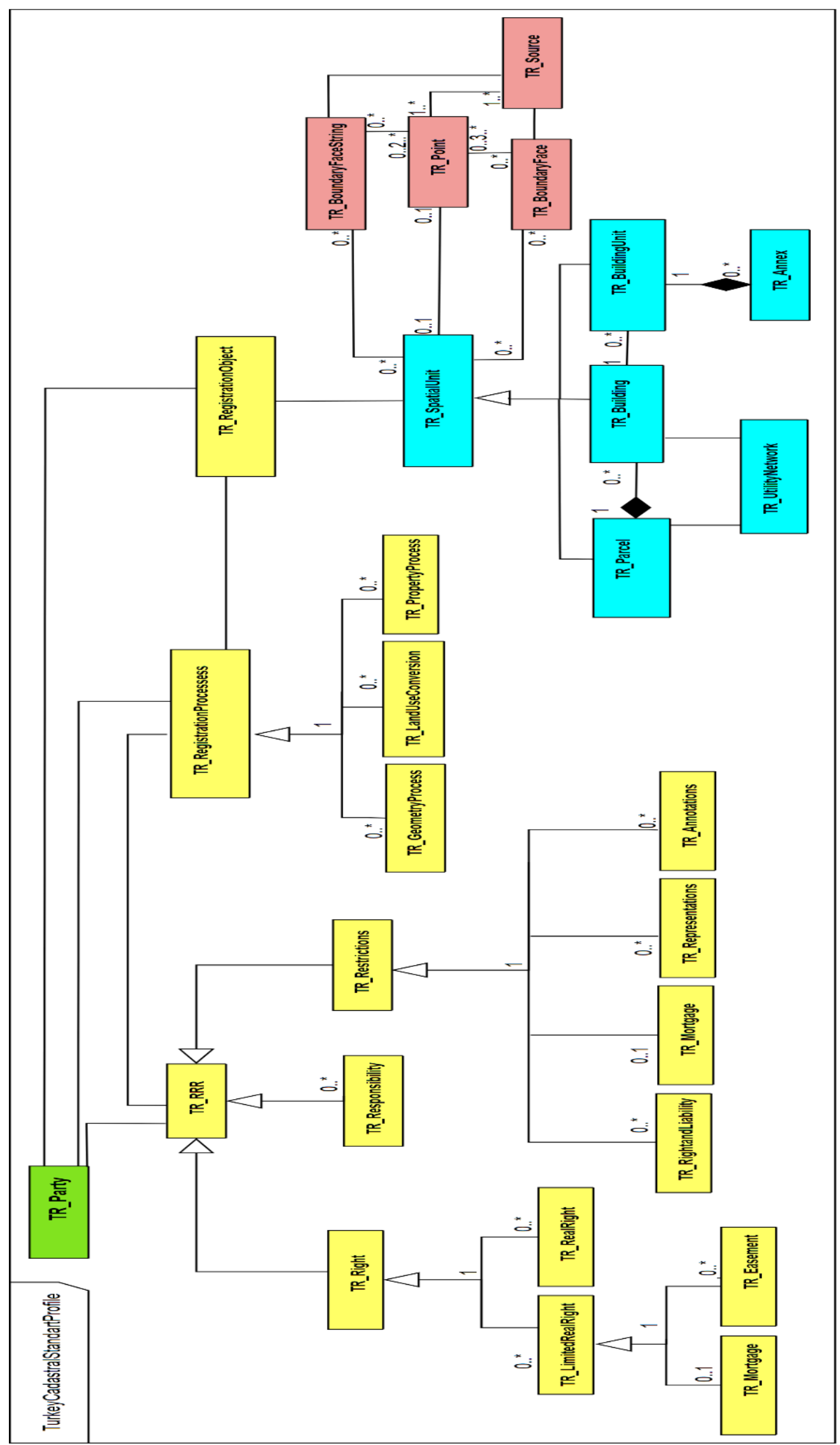

Figure 6: A general overview of 3D cadastral data model developed within the scope of the ISO 19152 and LADM standards. 
The international standards related to 3D cadastre are ISO 19152 and LADM, which are essential step in terms of standardization and communication of cadastre and land management systems. On the other hand, the other necessary components are OGC and INSPIRE standards that are based on positional data management as well as ISO standards. Also, the management of 3D data/rights/boundaries will be significantly facilitated. In this study, the international standards based on $3 \mathrm{D}$ cadastral surveying proposals for Turkey have been introduced. Also, the rule is proposed for 3D Turkish cadastre as a result of these proposals. These designed standards are essential in terms of establishing a basis for future institutional and scientific studies in Turkey.

As a result, the representation of 3D cadastral data models have been developed based on the international standard, which is LADM and a conceptual model design was made. Thus, it is concluded that the existing Turkish cadastral system and data organization are compatible with a data model based on international standards. Besides, the model is designed to be consistent with the developed 3D cadastral data management in Turkey. It will accelerate the establishment of spatial data infrastructure in Turkey by the designed model. Finally, 3D cadastral data model standards proposed with a controlled and rapid transition to information systems will be provided. Besides, the use of international 3D cadastral standards will not only provide interoperability but will also provide an international experience to provide better service for the Turkish cadastral system.

\section{References}

Aien, A. (2013). 3D cadastral data modelling (Doctoral Dissertation), University of Melbourne, Department of Infrastructure Engineering, Victoria, Australia.

Akinci, H., \& Comert, C. (2009). TUCBS ve INSPIRE teknik mimarisi, 12. Türkiye Harita Bilimsel ve Teknik Kurultayl, Ankara (In Turkish).

Alkan, M. (2005). Tapu ve kadastro verilerine yönelik zamansal coğrafi bilgi sistemi tasarımı (Doctoral Dissertation), Karadeniz Technical University, Graduate Institute of Natural and Applied Sciences, Trabzon, Turkey (in Turkish).

Alkan, M., \& Polat, Z. A. (2017). Design and development of LADM-based infrastructure for Turkey. Survey review, 49(356), $370-385$.

Alkan, M., Gursoy Surmeneli, H., \& Polat, Z.A. (2018). Design and Determine Cadastral and Land Management Performance of Turkey with Cadastre 2034 Vision, XXVI FIG Congress, Istanbul.

Ayazli, E. (2006). Üç boyutlu kadastro (Master Thesis). Yildiz Technical University, Graduate School of Natural and Applied Sciences, Istanbul, Turkey (in Turkish).

Aydin, C. C. (2008). Usage of underground space for 3D cadastre purposes and related problems in Turkey. Sensors, 8(11), 6972-6983.

Aydinoglu, A.C. (2007). ISO / TC211-coğrafi bilgi standartları, TMMOB Coğrafi Bilgi Sistemleri Kongresi, Trabzon (In Turkish).

Aydinoglu, A.C. (2010). Coğrafi veri yönetiminde standart kavramı, 3. Uzaktan algılama ve coğrafi bilgi sistemleri sempozyumu, Kocaeli (In Turkish).

Aydinoglu, A. C., \& Yomralioglu, T. (2010). A harmonised GI model for urban governance. Proceedings of the Institution of Civil Engineers-Municipal Engineer (Vol. 163, No. 2, pp. 65-76). Thomas Telford Ltd.

Aydinoglu, A. C., \& Inan, H. I. (2014). Developing land registry and cadastre base data model for land management applications. FIG Congress 2014.

Aydinoglu, A. C., \& Bovkir, R. (2017). Generic land registry and cadastre data model supporting interoperability based on international standards for Turkey. Land use policy, 68, 59-71.

Benhamu, M., \& Doytsher, Y. (2003). Toward a spatial 3D cadastre in Israel. Computers, Environment and Urban Systems, 27(4), 359374.

Coruhlu, Y. E., Demir, O., Yildiz, O., \& Cete, M. (2016). The relation between structured cultural heritages and condominium towards 3D cadastre. Survey review, 48(351), 438-449.

Cete, M., \& Inan, H.I. (2013). Kadastroda Modern Eğilimler ve Türkiye Kadastrosu, 14. Türkiye Harita Bilimsel ve Teknik Kurultayl, 
Ankara (In Turkish).

Doner, F., \& Biyik, C. (2007). Defining 2D Parcels in 3D Space by Using Elevation Data, FIG Working Week 2007 Hong Kong SAR, China.

Doner, F. (2010). Türk kadastro sistemi için üç boyutlu yaklaşım (Doctoral Dissertation), Karadeniz Technical University, Graduate Institute of Natural and Applied Sciences, Trabzon, Turkey (in Turkish).

Doner, F., Thompson, R., Stoter, J., Lemmen, C., Ploeger, H., van Oosterom, P., \& Zlatanova, S. (2010). 4D cadastres: First analysis of legal, organizational, and technical impact -With a case study on utility networks. Land Use Policy, 27(4), 1068-1081.

Doner, F., Thompson, R., Stoter, J., Lemmen, C., Ploeger, H., van Oosterom, P., \& Zlatanova, S. (2011). Solutions for 4D cadastre-with a case study on utility networks. International journal of geographical information science, 25(7), 1173-1189.

Doner, F., \& Biyik, C. (2013). Conformity of LADM for Modeling 3D/4D Cadastre Situations in Turkey, 5th Land Administration Domain Model Workshop, Kuala Lumpur, Malaysia.

Ekin, E., \& Cabuk, A. (2011). OGC Olanakları ile CBS Tabanlı Hizmet Yönetimi: Akıllı Altyapı, 6th International Advanced Technologies Symposium (IATS'11), Elazig (In Turkish).

Guo, R., Li, L., Ying, S., Luo, P., He, B., \& Jiang, R. (2013). Developing a 3D cadastre for the administration of urban land use: A case study of Shenzhen, China. Computers, Environment and Urban Systems, 40, 46-55.

Gursoy Surmeneli, H., \& Alkan, M. (2018). Design and Determine 3D Cadastral Systems: A Case Study of Turkey, 6th International FIG $3 D$ Cadastre Workshop, Delft, The Netherlands.

Hassan, M., \& Rahman, A. (2011). Unique identifier for 3D cadastre objects registration, The 2nd international workshop on 3D cadastres, Delft, The Netherlands.

Herdlevær, H. (2018). Cadastral template. Norwegian Mapping and Cadaster Authority Director Cadastral Department.

Karatas, K. (2007). Kentsel teknik alt yapı tesisleri, kadastrosu ve Türkiye'deki uygulamaların organizasyonu (Doctoral Dissertation), Karadeniz Technical University, Graduate Institute of Natural and Applied Sciences, Trabzon, Turkey (in Turkish).

Kumdakci, S. (2005). Kadastral amaçlı bilgi sistemlerinde 3 boyutlu modelleme ve görselleştirme tekniklerinin kullanılması konusunda bir araştırma (Master Thesis). Yildiz Technical University, Graduate School of Natural and Applied Sciences, Istanbul, Turkey (in Turkish).

Lemmen, C. H. J., van Oosterom, P. J. M., Uitermark, H. T., Zevenbergen, J. A., \& Cooper, A. K. (2011). Interoperable domain models: The ISO land administration domain model LADM and its external classes. UDMS 2011, Delft, The Netherlands.

Lemmen, C., van Oosterom, P., \& Bennett, R. (2015). The land administration domain model. Land use policy, 49, 535-545.

Mataraci, O. Yomralioglu, T., \& Cete, M. (2009). AB'de Kadastro Parselinin INSPIRE Direktifleri Kapsaminda Değerlendirilmesi ve Türkiye'nin Yeri. 14. Türkiye Harita Bilimsel ve Teknik Kurultayl, Ankara (In Turkish).

Paulsson, J., \& Paasch, J.M., (2011). 3D property research - A survey of the occurrence of legal topics in publications. The 2nd international workshop on $3 D$ Cadastres, Delft, The Netherlands.

Polat, Z. A., Alkan, M., \& Gursoy Surmeneli, H. (2017). Determining strategies for the cadastre 2034 vision using an AHP-Based SWOT analysis: A case study for the turkish cadastral and land administration system. Land Use Policy, 67, 151-166.

Rajabifard, A. (2014). 3D Cadastres and Beyond, 4. International Workshop on 3D Cadastres, Dubai, United Arab Emirates.

Simsion, G.C., \& Witt, G.C. (2005). Data modeling essentials (3rd ed.). Amsterdam; Boston: Morgan Kaufmann Publishers.

Sorensen, E.M. (2011). 3 Dimensional property rights in Denmark, 3D property design is working - Visualization not. The 2. international workshop on $3 D$ cadastres, Delft, The Netherlands.

Steudler, D. (2015). Dimension cadastre - stepping beyond limits. FIG working Week from the Wisdom of the Ages to the Challenges of the Modern World, Sofia, Bulgaria.

Stoter, J. E., \& Salzmann, M. E. (2003). Where do cadastral needs and technical possibilities meet? In van Oosterom, P.J.M., \& Lemmen C.H.J. (2003), Cadastral systems III, 3D cadastre. Computers, Environment and Urban Systems (CEUS).

Stoter, J.E. (2004). 3D Cadastre (Doctoral Dissertation). TU Delft, the Netherlands.

Stoter, J., Sørensen, E. M., \& Bodum, L. (2004). 3D registration of real property in Denmark. FIG Working Week, Athens, Greece.

Stoter, J. E., \& van Oosterom, P. J. M. (2005). Technological aspects of a full 3D cadastral registration. International Journal of Geographical Information Science, 19(6), 669-696.

Stoter, J., Ploeger, H., \& van Oosterom, P. (2013). 3D cadastre in the Netherlands: Developments and international 
applicability. Computers, Environment and Urban Systems, 40, 56-67.

Tjia, D., \& Coetzee, S. (2013). Application of the Land Administration Domain Model to the city of Johannesburg land information system. South African Journal of Geomatics, 2(3), 260-279.

van Oosterom, P., Ploeger, H., Stoter, J., Thompson, R., \& Lemmen, C. (2006). Aspects of a 4D cadastre: a first exploration. In In: Peoceedings of Shaping the Change, XXIII international FIG congress.

van Oosterom, P. (2018). Best Practices 3D Cadastres. International Federation of Surveyors (FIG): Copenhagen, Denmark.

URL-1: Turkey's National Geographic Information System Determination Standard Project: TUCBS conceptual model components, T. C. Ministry of Environment and Urbanization General Directorate of Geographical Information Systems. https://webdosya.csb.gov.tr/cs b/dokumanlar/cbs0008.pdf (Accessed: 7 April 2019).

URL-2: NEN 3610: Land-information terrain model - Terms, definitions and general rules for the classification and coding of objects related to the earth's surface. https://www.nen.nl/NEN-Shop-2/Standard/NEN-36101995-nl.htm (Accessed: 10 December 2018). 